OECD Trade and Environment Working Papers 2009/01

Environment and Regional

Trade Agreements:

\title{
Simone Gigli
}

\author{
Developments in 2008
}


Organisation de Coopération et de Développement Économiques

Organisation for Economic Co-operation and Development

24-Mar-2009

TRADE AND AGRICULTURE DIRECTORATE

English - Or. English

ENVIRONMENT DIRECTORATE

Joint Working Party on Trade and Environment

ENVIRONMENT AND REGIONAL TRADE AGREEMENTS:

DEVELOPMENTS IN 2008

OECD Trade and Environment Working Paper $\mathrm{N}^{\circ}$ 2009-01

by Simone Gigli 


\section{Abstract}

This document provides a second update on developments in the field of regional trade agreements and environment covering the period late 2007 to December 2008. It complements the 2007 publication "Environment and Regional Trade Agreements", and the first update presented to the JWPTE in December 2007 (COM/TAD/ENV/JWPTE/RD(2007)40/FINAL).

It is based on publicly available information and refers to agreements which have been signed by the Parties, though not all have entered into force yet. It also includes information on recent Trade Promotion Agreements (TPAs) which were not covered by the first study.

\section{Acknowledgements}

This report was written by Simone Gigli (consultant). It was discussed by the Joint Working Party on Trade and Environment in December 2007and cleared for declassification through written procedure. It is published under the responsibility of the Secretary-General.

All requests for permission to reproduce of translate all or part of this material should be submitted to rights@oecd.org. OECD Publishing, 2, rue André Pascal, 75775 Paris Cedex 16, France. 


\section{TABLE OF CONTENTS}

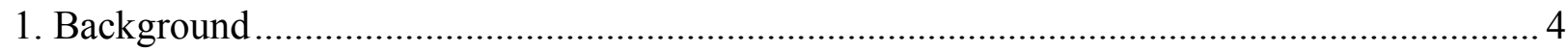

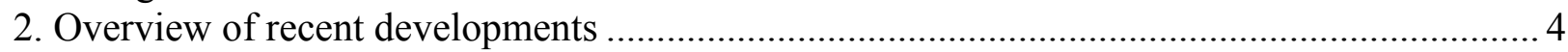

3. Further developments: instruments with possible environmental content.............................. 8

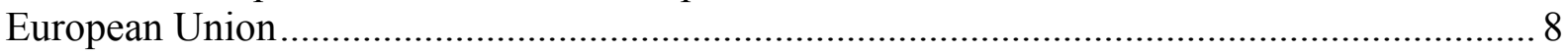

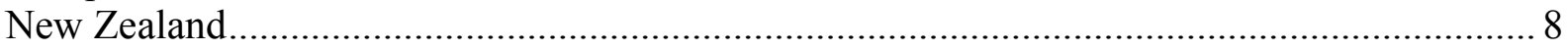

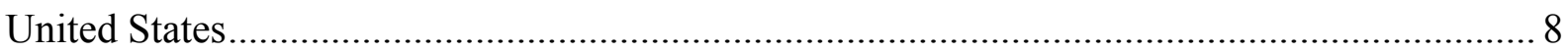

4. Examples of environmental provisions in recent trade agreements .................................... 10

Examples of environmental provisions in the body of the agreement ................................. 10

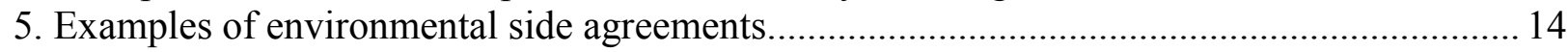

New Zealand-China Environment Cooperation Agreement ............................................ 14

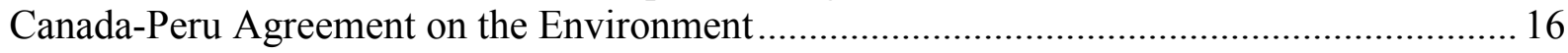

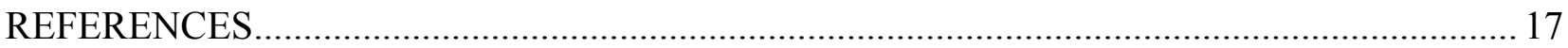

\section{Tables}

Table 1. Overview of recent trade agreements and their environmental provisions 4 


\section{Background}

In June 2007, the OECD published "Environment and Regional Trade Agreements", a study prepared under the aegis of the Joint Working Party on Trade and Environment (JWPTE). It analyses the ways in which governments deal with environmental issues in the context of regional trade agreements (RTAs), describes key provisions on environment in RTAs and examines countries' experience related to their negotiation and implementation. The study covers developments until end 2006.

At the JWPTE meeting in December 2007, the first update was presented (and subsequently unclassified, see COM/TAD/ENV/JWPTE/RD(2007)40/FINAL), covering developments in late 2006 and 2007. This document provides an update on developments in the field of RTAs and environment in late 2007 and 2008. It is based on publicly available information and refers to agreements which have been signed by the Parties, though not all have entered into force yet. It also includes information on recent Trade Promotion Agreements (TPAs) which were not covered by the first study, and on ongoing negotiations on which information is publicly available.

\section{Overview of recent developments}

Among OECD countries, recent developments with regard to trade agreements that contain environmental provisions or environmental side agreements concern Australia, Canada, the European Union, Japan, New Zealand, Turkey and the United States. These recent developments may relate to the signing of new agreements or the ratification and/or entry into force of earlier concluded agreements. In addition, several non-OECD countries have signed trade agreements with environmental provisions. Table 1 provides an overview of these agreements. ${ }^{1}$

Table 1. Overview of recent trade agreements and their environmental provisions

\begin{tabular}{|c|c|c|c|}
\hline Trade Agreements & $\begin{array}{c}\text { Status (as of Oct. } \\
2008 \text { ) }\end{array}$ & Environmental considerations & $\begin{array}{c}\text { Website (final text or } \\
\text { information) }\end{array}$ \\
\hline \multicolumn{4}{|c|}{ Agreements signed by Australia } \\
\hline $\begin{array}{l}\text { Australia-Chile Free } \\
\text { Trade Agreement }\end{array}$ & $\begin{array}{l}\text { Signed } 30 \text { July } 2008 ; \\
\text { expected to enter into } \\
\text { force } 6 \text { March } 2009\end{array}$ & $\begin{array}{l}\text { Preamble, Chapter } 10 \\
\text { (Investment), Chapter } 15 \\
\text { (Government Procurement), } \\
\text { Chapter } 18 \text { (Cooperation), Chapter } \\
22 \text { (General Provisions and } \\
\text { Exceptions) }\end{array}$ & $\begin{array}{l}\text { www.dfat.gov.au/GEO/chile } \\
\underline{\text { fta/Australia Chile FTA.pd }}\end{array}$ \\
\hline \multicolumn{4}{|c|}{ Agreements signed by Canada } \\
\hline $\begin{array}{l}\text { Canada-European } \\
\text { Free Trade } \\
\text { Association (EFTA) } \\
\text { Free Trade } \\
\text { Agreement }\end{array}$ & Signed 26 January 2008 & $\begin{array}{l}\text { Preamble, Chapter } 6 \text { (Exceptions } \\
\text { and Safeguards) }\end{array}$ & $\begin{array}{l}\text { www.international.gc.ca/tra } \\
\text { de-agreements-accords- } \\
\text { commerciaux/agr-acc/efta- } \\
\text { aele.aspx?lang=en\#2 }\end{array}$ \\
\hline
\end{tabular}

The overview covers those trade agreements that have recently been signed, ratified or entered into force as of October 2008. The list does not claim to be exhaustive. 


\begin{tabular}{|c|c|c|c|}
\hline $\begin{array}{l}\text { Canada-Peru Free } \\
\text { Trade Agreement, } \\
\text { including an } \\
\text { Agreement on the } \\
\text { Environment }\end{array}$ & Signed 29 May 2008 & $\begin{array}{l}\text { Preamble, Chapter } 1 \text { (Initial } \\
\text { Provisions and General } \\
\text { Definitions), Chapter } 5 \text { (Sanitary } \\
\text { and Phytosanitary Measures), } \\
\text { Chapter } 6 \text { (Technical Barriers to } \\
\text { Trade), Chapter } 8 \text { (Investment), } \\
\text { Chapter } 11 \text { (Financial Services), } \\
\text { Chapter } 14 \text { (Government } \\
\text { Procurement), Chapter } 17 \\
\text { (Environment), Chapter } 20 \\
\text { (Administration of the Agreement), } \\
\text { Chapter } 21 \text { (Dispute Settlement), } \\
\text { Chapter } 22 \text { (Exceptions) }\end{array}$ & $\begin{array}{l}\text { www.international.gc.ca/tra } \\
\text { de-agreements-accords- } \\
\text { commerciaux/agr-acc/peru- } \\
\text { perou/peru-perou- } \\
\text { table.aspx } \\
\text { Agreement on the } \\
\text { Environment: } \\
\text { www.international.gc.ca/tra } \\
\text { de-agreements-accords- } \\
\text { commerciaux/assets/pdfs/ } \\
\text { Canada- } \\
\text { Peru Environment-en.pdf }\end{array}$ \\
\hline $\begin{array}{l}\text { Canada-Colombia } \\
\text { Free Trade } \\
\text { Agreement, including } \\
\text { an Agreement on the } \\
\text { Environment }\end{array}$ & $\begin{array}{l}\text { Concluded } 7 \text { June 2008, } \\
\text { currently pending } \\
\text { ratification }\end{array}$ & $\begin{array}{l}\text { [Text of the agreement is not } \\
\text { publicly available.] } \\
\text { Trade-related environmental } \\
\text { provisions contained in the FTA: } \\
\text { - provide for specific Multilateral } \\
\text { Environmental Agreements } \\
\text { (MEA) (e.g., Montreal Protocol } \\
\text { on Substances that Deplete } \\
\text { the Ozone Layer) to prevail in } \\
\text { the event of an inconsistency } \\
\text { between an FTA obligation } \\
\text { and the obligations in the } \\
\text { MEA; } \\
\text { encourage the Parties not to } \\
\text { weaken their domestic health, } \\
\text { safety or environmental } \\
\text { measures to attract } \\
\text { investment; and } \\
\text { allow the Parties to take } \\
\text { measures necessary to protect } \\
\text { human, animal and plant life or } \\
\text { health, that may be } \\
\text { inconsistent with trade or } \\
\text { investment obligations. } \\
\text { The FTA includes a parallel } \\
\text { Agreement on the Environment } \\
\text { containing key environmental } \\
\text { obligations and a framework to } \\
\text { undertake environmental } \\
\text { cooperation activities. }\end{array}$ & $\begin{array}{l}\text { www.international.gc.ca/tra } \\
\text { de-agreements-accords- } \\
\text { commerciaux/agr- } \\
\text { acc/andean-andin/can- } \\
\text { colombia-colombie.aspx } \\
\text { Agreement on the } \\
\text { Environment (Fact Sheet): } \\
\text { www.international.gc.ca/tra } \\
\text { de-agreements-accords- } \\
\text { commerciaux/agr- } \\
\text { acc/colombia- } \\
\text { colombie/facts-fiches- } \\
\text { env.aspx?lang=en }\end{array}$ \\
\hline $\begin{array}{l}\text { Canada-Jordan Free } \\
\text { Trade Agreement, } \\
\text { including an } \\
\text { Agreement on the } \\
\text { Environment }\end{array}$ & $\begin{array}{l}\text { Concluded } 25 \text { August } \\
2008, \text { currently pending } \\
\text { ratification }\end{array}$ & $\begin{array}{l}\text { [Text of the agreement is not } \\
\text { publicly available.] } \\
\text { The Free Trade Agreement sets } \\
\text { out several provisions that strive to } \\
\text { protect the environment by: } \\
\text { - highlighting the importance of } \\
\text { environmental conservation } \\
\text { and protection and the } \\
\text { promotion of sustainable } \\
\text { development; } \\
\text { - reaffirming the Parties' } \\
\text { commitments to Multilateral } \\
\text { Environmental Agreements } \\
\text { (MEAs) and providing for } \\
\text { specific MEAs (e.g. Montreal } \\
\text { Protocol on Substances that } \\
\text { Deplete the Ozone Layer) to }\end{array}$ & $\begin{array}{l}\text { www.international.gc.ca/tra } \\
\text { de-agreements-accords- } \\
\text { commerciaux/agr- } \\
\text { acc/jordan- } \\
\text { jordanie/index.aspx?lang=e } \\
\underline{\mathrm{n}} \\
\text { Agreement on the } \\
\text { Environment (Fact Sheet): } \\
\text { www.international.gc.ca/tra } \\
\text { de-agreements-accords- } \\
\text { commerciaux/agr- } \\
\text { acc/jordan- } \\
\text { jordanie/index.aspx?lang=e } \\
\underline{\mathrm{n}}\end{array}$ \\
\hline
\end{tabular}




\begin{tabular}{|c|c|c|c|}
\hline & & $\begin{array}{l}\text { prevail in the event of an } \\
\text { inconsistency between an FTA } \\
\text { obligation and the obligations } \\
\text { in the MEAs; and } \\
\text { - allowing the Parties to take } \\
\text { measures necessary to protect } \\
\text { human, animal and plant life or } \\
\text { health, which may be } \\
\text { inconsistent with trade or } \\
\text { investment obligations. } \\
\text { The Agreement on the } \\
\text { Environment contains provisions } \\
\text { relating to environmental } \\
\text { protection, environment-related } \\
\text { cooperation activities, } \\
\text { enforcement of environmental } \\
\text { standards, and complaints } \\
\text { procedure/dispute resolution. }\end{array}$ & \\
\hline \multicolumn{4}{|c|}{ Agreements signed by the European Union } \\
\hline $\begin{array}{l}\text { EU-CARIFORUM }{ }^{2} \\
\text { Economic Partnership } \\
\text { Agreement }\end{array}$ & $\begin{array}{l}\text { Initialled } 16 \text { December } \\
2007 ; \text { Signed } 15 \\
\text { October } 2008 ; \text { currently } \\
\text { pending ratification }\end{array}$ & $\begin{array}{l}\text { Preamble, PART I (Trade } \\
\text { Partnership for Sustainable } \\
\text { Development); PART II (Trade and } \\
\text { Trade-related Matters) / TITLE I } \\
\text { (Trade in Goods): Chapter } 5 \\
\text { (Agriculture and Fisheries), } \\
\text { CHAPTER } 6 \text { (Technical Barriers to } \\
\text { Trade); TITLE II (Investment, } \\
\text { Trade in Services and E- } \\
\text { commerce): Chapter } 2 \\
\text { (Commercial Presence); } \\
\text { TITLE III (Trade-related Issues): } \\
\text { Chapter } 5 \text { (Regulatory Framework) } \\
\text { - Section } 7 \text { (Tourism Services); } \\
\text { TITLE IV (Trade-related Issues): } \\
\text { Chapter } 2 \text { (Innovation and } \\
\text { Intellectual Property) - Section } 1 \\
\text { (Innovation), Section } 2 \text { (Intellectual } \\
\text { Property), Chapter } 4 \\
\text { (Environment) }\end{array}$ & $\begin{array}{l}\text { http://trade.ec.europa.eu/d } \\
\text { oclib/docs/2008/april/tradoc } \\
\text { 138569.pdf }\end{array}$ \\
\hline \multicolumn{4}{|c|}{ Agreements signed by Japan } \\
\hline $\begin{array}{l}\text { ASEAN }{ }^{3} \text {-Japan } \\
\text { Comprehensive } \\
\text { Economic Partnership } \\
\text { Agreement }\end{array}$ & $\begin{array}{l}\text { Signed in April 2008; } \\
\text { entered into force } 1 \\
\text { December } 2008\end{array}$ & $\begin{array}{l}\text { Chapter } 2 \text { (Trade in Goods), } \\
\text { Chapter } 5 \text { (Standards, Technical } \\
\text { Regulations and Conformity } \\
\text { Assessment Procedure), Chapter } \\
8 \text { (Economic Cooperation) }\end{array}$ & $\begin{array}{l}\text { www.mofa.go.jp/policy/eco } \\
\text { nomy/fta/asean/agreement. } \\
\text { pdf }\end{array}$ \\
\hline $\begin{array}{l}\text { Japan-Brunei } \\
\text { Darussalam Economic } \\
\text { Partnership }\end{array}$ & $\begin{array}{l}\text { Signed in June } 2007 ; \\
\text { entered into force } 31 \\
\text { July } 2008\end{array}$ & $\begin{array}{l}\text { Preamble, Chapter } 5 \text { (Investment), } \\
\text { Chapter } 7 \text { (Energy), Chapter } 9 \\
\text { (Cooperation) }\end{array}$ & $\begin{array}{l}\text { www.mofa.go.jp/region/asi } \\
\text { a- } \\
\text { paci/brunei/epa0706/agree }\end{array}$ \\
\hline
\end{tabular}

2 CARIFORUM (Caribbean Forum of African, Caribbean and Pacific (ACP) States) member countries: Antigua and Barbuda, Bahamas, Barbados, Belize, Dominica, the Dominican Republic, Grenada, Guyana, Haiti, Jamaica, Saint Lucia, Saint Vincent and the Grenadines, Saint Christopher and Nevis, Surinam, and Trinidad and Tobago.

ASEAN (Association of Southeast Asian Nations) member countries: Brunei Darussalam, the Kingdom of Cambodia, the Republic of Indonesia, the Lao People's Democratic Republic, Malaysia, the Union of Myanmar, the Republic of the Philippines, the Republic of Singapore, the Kingdom of Thailand, and the Socialist Republic of Viet Nam. 
COM/TAD/ENV/JWPTE(2008)41/FINAL

\begin{tabular}{|c|c|c|c|}
\hline Agreement & & & ment.pdf \\
\hline $\begin{array}{l}\text { Japan-Indonesia } \\
\text { Economic Partnership } \\
\text { Agreement }\end{array}$ & $\begin{array}{l}\text { Signed in August } 2007 ; \\
\text { entered into force } 1 \text { July } \\
2008\end{array}$ & $\begin{array}{l}\text { Chapter } 5 \text { (Investment), Chapter } 8 \\
\text { (Energy and Mineral Sources), } \\
\text { Chapter } 13 \text { (Cooperation) }\end{array}$ & $\begin{array}{l}\text { www.mofa.go.jp/region/asi } \\
\text { a- } \\
\text { paci/indonesia/epa0708/ag } \\
\text { reement.pdf }\end{array}$ \\
\hline \multicolumn{4}{|c|}{ Agreements signed by New Zealand } \\
\hline $\begin{array}{l}\text { New Zealand-China } \\
\text { Free Trade } \\
\text { Agreement, including } \\
\text { an Environment } \\
\text { Cooperation } \\
\text { Agreement }\end{array}$ & $\begin{array}{l}\text { Signed } 7 \text { April 2008; } \\
\text { entered into force } 1 \\
\text { October } 2008\end{array}$ & $\begin{array}{l}\text { Preamble, Chapter } 8 \text { (Technical } \\
\text { Barriers to Trade), Chapter } 14 \\
\text { (Cooperation), Chapter } 17 \\
\text { (Exceptions) }\end{array}$ & $\begin{array}{l}\text { http://chinafta.govt.nz/1- } \\
\text { The-agreement/2-Text-of- } \\
\text { the-agreement/0- } \\
\text { downloads/NZ-ChinaFTA- } \\
\text { Agreement-text.pdf } \\
\text { Environment Cooperation } \\
\text { Agreement: } \\
\text { www.chinafta.govt.nz/1- } \\
\text { The-agreement/1-Key- } \\
\text { outcomes/0- } \\
\text { downloads/ECA-NZ.pdf }\end{array}$ \\
\hline \multicolumn{4}{|c|}{ Agreements signed by Turkey } \\
\hline $\begin{array}{l}\text { Turkey-Albania Free } \\
\text { Trade Agreement }\end{array}$ & $\begin{array}{l}\text { Entered into force } 1 \text { May } \\
2008\end{array}$ & Article 31 (General Exceptions) & $\begin{array}{l}\text { www.dtm.gov.tr/dtmadmin/ } \\
\text { upload/AB/SerbestTicaretD } \\
\text { b/Arnavutluk/ARN EN/01- } \\
\text { MAIN TEXT.doc } \\
\end{array}$ \\
\hline \multicolumn{4}{|c|}{ Agreements signed by the United States } \\
\hline $\begin{array}{l}\text { US-Oman Free Trade } \\
\text { Agreement }\end{array}$ & $\begin{array}{l}\text { Signed in September } \\
2006 ; \text { Entered into force } \\
1 \text { January } 2009\end{array}$ & $\begin{array}{l}\text { Preamble, Chapter } 6 \text { (Sanitary and } \\
\text { Phytosanitary Measures), Chapter } \\
17 \text { (Environment), Chapter } 20 \\
\text { (Dispute Settlement), Chapter } 21 \\
\text { (Exceptions) }\end{array}$ & $\begin{array}{l}\frac{\text { www.ustr.gov/Trade Agree }}{\text { ments/Bilateral/Oman FTA }} \\
\underline{\text { /Final Text/Section Index. }} \\
\underline{\text { html }}\end{array}$ \\
\hline $\begin{array}{l}\text { US-Peru Trade } \\
\text { Promotion Agreement, } \\
\text { including Environment } \\
\text { Cooperation } \\
\text { Agreement }\end{array}$ & $\begin{array}{l}\text { Entered into force } 1 \\
\text { February 2009; } \\
\text { parallel Environment } \\
\text { Cooperation Agreement } \\
\text { signed } 26 \text { July } 2006\end{array}$ & $\begin{array}{l}\text { Preamble, Chapter } 6 \text { (Sanitary and } \\
\text { Phytosanitary Measures), Chapter } \\
9 \text { (Government Procurement), } \\
\text { Chapter } 10 \text { (Investment), Chapter } \\
18 \text { (Environment), Chapter } 21 \\
\text { (Dispute Settlement), Chapter } 22 \\
\text { (Exceptions) } \\
\text { The parallel Peru Environment } \\
\text { Cooperation Agreement, aiming at } \\
\text { establishing a framework for } \\
\text { enhancing bilateral and/or regional } \\
\text { environmental cooperation } \\
\text { between the Parties contains } \\
\text { provisions related to, inter alia, } \\
\text { cooperation mechanisms; } \\
\text { participation in and operation of } \\
\text { the Environmental Cooperation } \\
\text { Commission; the work program } \\
\text { and cooperation areas; necessary } \\
\text { financial, human, technological } \\
\text { and organisational resources; } \\
\text { opportunities for public } \\
\text { participation }\end{array}$ & $\begin{array}{l}\text { www.ustr.gov/Trade Agree } \\
\text { ments/Bilateral/Peru TPA/ } \\
\text { Final Texts/Section Index. } \\
\text { html } \\
\text { Environment Cooperation } \\
\text { Agreement: } \\
\text { http://www.state.gov/g/oes/ } \\
\text { env/trade/81638.htm }\end{array}$ \\
\hline
\end{tabular}




\begin{tabular}{|c|c|c|c|}
\hline \multicolumn{4}{|c|}{ Agreements signed by non-OECD countries } \\
\hline $\begin{array}{l}\text { Pakistan-Malaysia } \\
\text { Closer Economic } \\
\text { Partnership } \\
\text { Agreement }\end{array}$ & $\begin{array}{l}\text { Signed } 8 \text { November } \\
2007 \text {; entered into force } \\
1 \text { January } 2008\end{array}$ & $\begin{array}{l}\text { Chapter } 6 \text { (Sanitary and } \\
\text { Phytosanitary Measures) }\end{array}$ & $\begin{array}{l}\text { www.commerce.gov.pk/PM } \\
\text { FTA/PAk-Malaysia- } \\
\underline{\text { FTA(TXT).pdf }}\end{array}$ \\
\hline $\begin{array}{l}\text { Chile-Panama Free } \\
\text { Trade Agreement }\end{array}$ & $\begin{array}{l}\text { Entered into force } 7 \\
\text { March } 2008\end{array}$ & $\begin{array}{l}\text { Preamble } \\
\text { The FTA with Panama } \\
\text { incorporates environmental } \\
\text { provisions in a side agreement : } \\
\text { Environmental Cooperation } \\
\text { Agreement }\end{array}$ & $\begin{array}{l}\text { www.direcon.cl/pdf/TLC C } \\
\underline{\text { hile Panama.pdf }}\end{array}$ \\
\hline $\begin{array}{l}\text { El Salvador- } \\
\text { Honduras-Taiwan } \\
\text { Free Trade } \\
\text { Agreement }\end{array}$ & $\begin{array}{l}\text { Signed } 7 \text { May } 2007 ; \\
\text { entered into force } 1 \\
\text { January } 2008 \text { for El } \\
\text { Salvador and Taiwan, } \\
\text { and } 15 \text { July } 2008 \text { for } \\
\text { Honduras }\end{array}$ & $\begin{array}{l}\text { Chapter } 9 \text { (Standardisation } \\
\text { Measures, Metrology and } \\
\text { Authorisation Procedures), } \\
\text { Chapter } 17 \text { (Cooperation) }\end{array}$ & $\begin{array}{l}\text { www.sice.oas.org/Trade/SL } \\
\text { V- } \\
\text { HND TWN FTA s/Index } \\
\underline{\text { s.asp }}\end{array}$ \\
\hline $\begin{array}{l}\text { Peru-Singapore Free } \\
\text { Trade Agreement }\end{array}$ & $\begin{array}{l}\text { Signed } 29 \text { May } 2008 ; \\
\text { expected to enter into } \\
\text { force early } 2009\end{array}$ & $\begin{array}{l}\text { Chapter } 6 \text { (Sanitary and } \\
\text { Phytosanitary Measures), Chapter } \\
7 \text { (Technical Barriers to Trade), } \\
\text { Chapter } 7 \text { (Investment), Chapter } \\
18 \text { (Exceptions) }\end{array}$ & $\begin{array}{l}\text { www.sice.oas.org/TPD/PE } \\
\text { R SGP/Final Texts PER } \\
\text { SGP s/Index_s.asp } \\
\text { [Spanish] }\end{array}$ \\
\hline
\end{tabular}

\section{Further developments: instruments with possible environmental content}

\section{European Union}

Negotiations aimed at concluding wide-ranging bi-regional Association Agreements (including a Free Trade Agreement) between the EU and the Andean Community as well as between the EU and Central-America are under way since mid 2007, with sustainable development and environmental issues constituting an important part of the talks.

\section{New Zealand}

A range of countries are currently negotiating trade agreements, and a few of them provide information on their websites about progress in the negotiations. For example, the third round of negotiations for the New Zealand-Gulf Cooperation Council (GCC) FTA were held in Riyadh on 21-23 June 2008. The negotiations made useful progress across a number of areas including goods, services, government procurement and sanitary and phytosanitary (SPS) issues. The next round of negotiations has been set for late October, and will be held in New Zealand. A background paper on the negotiations of the New Zealand-Gulf Cooperation Council (GCC) FTA states that the "aim of the FTA, at this stage, would be to cover substantially all trade, including goods, services and investment, and other issues including trade and labour, trade and environment, government procurement and intellectual property" (New Zealand Ministry of Foreign Affairs and Trade, 2007).

\section{United States}

On 2 October 2008, continuing to advance their bilateral trade relations, the governments of the United States and Uruguay signed two protocols to their bilateral Trade and Investment 
Framework Agreement (TIFA). The two protocols cover substantive commitments in the areas of trade facilitation and public participation in trade and environment. In addition, the governments signed a Memorandum of Understanding to advance cooperation on renewable energy and energy efficiency. Both governments pledged continued cooperation in these areas and dialogue also progresses under the TIFA work program. This ongoing dialogue may result in the conclusion of additional protocols in the future (Office of the United States Trade Representative, 2008a).

On 22 September 2008, the United States announced the launch of negotiations to join the Trans-Pacific Strategic Economic Partnership (TPP), a comprehensive Free Trade Agreement concluded by Brunei-Darussalam, Chile, New Zealand and Singapore, as a vehicle for advancing Trans-Pacific wide economic integration. The United States and the Trans-Pacific partners will negotiate the terms of US participation in the Agreement, which entered into force in 2006. The TPP is a high-standard agreement that will facilitate trade and investment and promote U.S. interests on such issues as intellectual property rights, standards, transparency, labor and environment (Office of the United States Trade Representative, 2008b).

In May 2007, the US announced bipartisan agreement on trade policy relating to FTAs with Peru, Colombia, Panama and Korea. Along with labour, intellectual property, investment, government procurement and port security, environment is an area affected by the new trade policy template (see Box 1).

\section{Box 1. US: Environmental stipulations under bipartisan trade deal}

- The Administration and Congress have agreed to incorporate a specific list of multilateral environmental agreements (MEAs) in our FTAs.

- The list includes (with abbreviated titles) the Convention on International Trade in Endangered Species (CITES), Montreal Protocol on Ozone Depleting Substances, Convention on Marine Pollution, InterAmerican Tropical Tuna Convention (IATTC), Ramsar Convention on Wetlands, International Whaling Convention (IWC), and Convention on Conservation of Antarctic Marine Living Resources (CCAMLR).

- The United States is a signatory to all of these agreements. The United States takes seriously its obligations under these MEAs. We have nothing to fear from taking on FTA commitments for these agreements as well and subjecting those commitments to the FTA dispute settlement process where trade or investment are affected.

- We have also agreed to alter the non-derogation obligation for environmental laws from a "strive to" to a "shall" obligation, with allowance for waivers permitted under law as long as it does not violate the MEA. For the United States, this obligation is limited to federal laws and should not affect our implementation of these laws.

- $\quad$ Finally, we have agreed that all of our FTA environmental obligations will be enforced on the same basis as the commercial provisions of our agreements - same remedies, procedures, and sanctions. Previously, our environmental dispute settlement procedures focused on the use of fines, as opposed to trade sanctions, and were limited to the obligation to effectively enforce environmental laws.

- In connection with the Peru FTA, we have agreed to work with the Government of Peru on comprehensive steps to address illegal logging, including of endangered mahogany, and to restrict imports of products that are harvested and traded in violation of CITES. 


\section{Examples of environmental provisions in recent trade agreements}

Many trade agreements recently concluded by OECD countries (and some by non-OECD countries) include environmental provisions in the body of the agreement. The majority of these agreements include a reference to the environment in the Preamble. In addition, a number of agreements contain environmental considerations in provisions on investment, government procurement, dispute settlement, and environmental exceptions to trade disciplines. Some contain a detailed chapter on the environment and/or a chapter on sanitary and phytosanitary measures (SPS). The three recent FTAs by Canada (Canada-Peru, Canada-Columbia, Canada-Jordan) are accompanied by an Agreement on the Environment, and the New Zealand-China FTA has been negotiated together with an Environment Cooperation Agreement.

\section{Examples of environmental provisions in the body of the agreement}

Examples of provisions in the body of the agreement include:

\section{- Reference to the environment and environmental protection in the Preamble}

Under the Australia-Chile FTA, Parties are resolved to "IMPLEMENT this Agreement in a manner consistent with sustainable development and environmental protection and conservation".

The Parties of the Japan-Brunei Darussalam EPA recognise "that economic development, social development and environmental protection are interdependent and mutually reinforcing components of sustainable development and that the economic partnership can play an important role in promoting sustainable development".

Parties of the Chile-Panama FTA Chile-Panama agree "To implement the agreement in a manner consistent with the protection and conservation of the environment; to promote economic development in a manner consistent with the protection and conservation of the environment, as well as sustainable development; to conserve, protect and improve the environment, even with the management of natural resources in their respective territories, through multilateral environmental agreements to which they are parties". [unofficial translation]

- $\quad$ A detailed chapter on the environment

In chapter 17 of the Canada-Peru FTA, the Parties "recognize that each Party has sovereign rights and responsibilities to conserve and protect its environment, and affirm their environmental obligations under their domestic law, as well as their international obligations under multilateral environmental agreements" and "recognize the mutual supportiveness between trade and environment policies and the need to implement this Agreement in a manner consistent with environmental protection and conservation and the sustainable use of their resources" (Article 1701, paragraphs 1 and 2). The chapter further summarises the Parties' mutual obligations as set out in the Agreement on the Environment (side agreement) and contains provisions on the Relationship between the FTA and the Agreement on the Environment (Article 1703). 
Chapter 18 of the US-Peru TPA provides: "Recognizing that each Party has sovereign rights and responsibilities with respect to its natural resources, the objectives of this Chapter are to contribute to the Parties' efforts to ensure that trade and environmental policies are mutually supportive, to promote the optimal use of resources in accordance with the objective of sustainable development, and to strive to strengthen the links between the Parties' trade and environmental policies and practices, which may take place through environmental cooperation and collaboration."

The chapter further contains detailed provisions on the Levels of Protection (Art. 18.1), Environmental Agreements (Art. 18.2), Enforcement of Environmental Laws (Art. 18.3), Procedural Matters (Art. 18.4), Mechanisms to Enhance Environmental Performance (Art. 18.5), Environmental Affairs Council (Art. 18.6), Opportunities for Public Participation (Art. 18.7), Submissions on Enforcement Matters (Art. 18.8), Factual Records and Related Cooperation (Art. 18.9), Environmental Cooperation (Art. 18.10), Biological Diversity (Art. 18.11), Environmental Consultations and Panel Procedure (Art. 18.12), Relationship to Environmental Agreements (Art. 18.13), Definitions (Art. 18.14), Covered [Multilateral Environmental] Agreements (Annex 18.2), Annex on Forest Sector Governance (Annex 18.3.4).

The US-Peru TPA, reflecting the "Bipartisan Trade Deal," builds on and extends the United States' previous approach to FTAs. It contains innovative elements such as the obligation to implement seven specific multilateral environmental agreements to which the Parties are party; the forest governance annex; and the availability of the dispute settlement mechanism with respect to all obligations in the Environment Chapter, not just the obligation to effectively enforce environmental laws.

\section{- Environmental considerations in provisions on government procurement}

The Canada-Peru FTA provides in Chapter 14 relating to the procurement of goods and services that "nothing in this Chapter shall be construed to prevent a Party from adopting or maintaining measures: [...] (b) necessary to protect human, animal, or plant life or health; [...]"(paragraph 2). It further states that: "The Parties understand that paragraph 2(b) includes environmental measures necessary to protect human, animal or plant life or health" (paragraph 3, Article 1402, Security and General Exceptions).

\section{- $\quad$ Binding dispute settlement mechanisms with respect to environmental obligations}

All RTAs signed by the US contain various mechanisms to resolve disputes arising in relation with commitments under the Environment Chapter, although recourse to formal dispute settlement mechanisms under the Dispute Settlement chapter is generally limited to disputes linked to the (binding) obligation to enforce environmental laws. In the more recent agreements such as the US-Peru TPA, as well as FTAs with the Republic of Korea, Panama and Colombia, the whole Environment chapter is subject to formal dispute settlement. According to Article 21.5 (Intervention of the Commission) of the US-Peru TPA: "A consulting Party may also request in writing a meeting of the Commission where consultations have been held pursuant to Article 17.7 (Cooperative Labor Consultations), 18.12 (Environmental Consultations and Panel Procedure), or 7.7 (Committee on Technical Barriers to Trade)." In case an arbitral panel needs to be 
established (see Article 21.6), "The Parties shall apply the following procedures in selecting a panel: [...] (d) each disputing Party shall endeavor to select panelists who have expertise or experience relevant to the subject matter of the dispute. In addition, in any dispute arising under Chapter Seventeen (Labor) or Eighteen (Environment), panelists other than those selected by lot shall have expertise or experience relevant to the subject matter under dispute" (Article 21.9, Panel Selection).

- Environmental exceptions to trade disciplines ${ }^{4}$

The New Zealand-China FTA contains a General Exceptions clause (Article 200) that provides: "1. For the purposes of this Agreement, Article XX of GATT 1994 and its interpretative notes and Article XIV of GATS (including its footnotes) are incorporated into and made part of this Agreement, mutatis mutandis. 2. The Parties understand that the measures referred to in Article XX(b) of GATT 1994 and Article XIV(b) of GATS, as incorporated into this Agreement, can include environmental measures necessary to protect human, animal or plant life or health, and Article XX(g) of GATT 1994, as incorporated into this Agreement, applies to measures relating to the conservation of living and nonliving exhaustible natural resources, subject to the requirement that they are not applied in a manner which would constitute a means of arbitrary or unjustifiable discrimination or a disguised restriction on trade in goods or services or investment."

- $\quad$ Sanitary and phytosanitary measures (SPS)

The objective of chapter 6 on Sanitary and Phytosanitary Measures of the Closer Economic Partnership Agreement between Pakistan and Malaysia is to "protect human, animal or plant life or health in the territory of the countries of the Parties, and to provide a framework to address any bilateral sanitary and phytosanitary matters so as to facilitate and increase trade between the countries of the Parties." This chapter further defines the Scope and Coverage as well as General Provisions, and provides for the implementation of a Focal Point " $\mathrm{t}$ ]o facilitate the implementation of this Chapter and cooperation between the Parties [...]" and a Technical Working Group "where a matter covered under this Chapter cannot be clarified or resolved through the focal points".

Article 44 (Scope) of Chapter 5 (Standards, Technical Regulations and Conformity Assessment Procedures) of the ASEAN-Japan Comprehensive Economy Partnership provides that: "Nothing in this Chapter shall limit the right of a Party to prepare, adopt and apply standards and technical regulations, to the extent necessary, to fulfil a legitimate objective. Such legitimate objectives are, inter alia, national security requirements; the prevention of deceptive practices; protection of human health or safety, animal or plant life or health, or the environment. In pursuance of this, each Party retains all authority to interpret its laws, regulations and administrative provisions."

\footnotetext{
${ }^{4}$ Other Agreements containing environmental exceptions include the US-Peru Trade Promotion Agreement and the ASEAN-Japan Comprehensive Economy Partnership.
} 


\section{- Cooperation}

In chapter 9 of the Japan-Brunei Darussalam EPA, environment is listed as a field of cooperation (Article 102h) between the two Parties which have agreed to "promote cooperation under this Agreement for their mutual benefits in order to liberalise and facilitate trade and investment between the Parties and to promote the well-being of the peoples of both Parties" (Article 101).

The Cooperation chapter of the New Zealand-China FTA (chapter 17) refers to the environmental side agreement through which better cooperation on environmental matters should be achieved: "The Parties shall enhance their communication and cooperation on labour and environment matters through both the Memorandum of Understanding on Labour Cooperation and the Environment Cooperation Agreement between the Parties" (Article 177).

\section{- Investment clauses and commitments to maintain environmental standards}

Some chapters on investment contain exception and exclusion provisions related to environmental measures and environmental protection. Chapter 10 of the Australia-Chile FTA, for example, states that "Provided that such measures are not applied in an arbitrary or unjustifiable manner, or do not constitute a disguised restriction on international trade or investment, paragraphs 1(b), (c), and (f), and 2(a) and (b), shall not be construed to prevent a Party from adopting or maintaining measures, including environmental measures: [...] (ii) necessary to protect human, animal, or plant life or health; or (iii) related to the conservation of living or non-living exhaustible natural resources" (Article 10.7).

Under the Japan-Indonesia EPA "Each Party recognizes that it is inappropriate to encourage investments by investors of the other Party by relaxing its environmental measures. To this effect each Party should not waive or otherwise derogate from such environmental measures as an encouragement for establishment, acquisition or expansion of investments in its Area" (Article74).

- Environmental aspects in relation to the use of energy and mineral resources

The Japan-Indonesia EPA, in chapter 8, contains provisions regarding the use of energy and mineral resources. In this context, Article 102 provides that " 1 . Each Party, in pursuit of sustainable development and taking into account its obligations under those international agreements concerning environment to which it is a party, confirms the importance of avoiding or minimizing, in an economically efficient manner, harmful environmental impacts of all activities related to energy and mineral resources in its Area. 2. Each Party shall: (a) take account of environmental considerations, in accordance with its laws and regulations, throughout the process of formulation and implementation of its policy on energy and mineral resources; (b) encourage favourable conditions for the transfer and dissemination of technologies that contribute to the protection of environment, consistent with the adequate and effective protection of intellectual property rights; and (c) promote public awareness of environmental impacts 
of activities related to energy and mineral resources and of the scope for and the costs associated with the prevention or abatement of such impacts."

\section{Examples of environmental side agreements}

Some countries' objective to develop sound trade and environment policies that mutually support the goal of sustainable development is realised environmental side agreements with formal treaty status that are linked to the actual trade agreement.

\section{New Zealand-China Environment Cooperation Agreement}

In the case of New Zealand, the "2001 Framework for Integrating Environment Standards and Trade Agreements" provides guidance for the negotiation of environmental issues in the context of New Zealand's overall free trade negotiations.

Under these agreements, each country undertakes:

- to ensure that their environmental laws, regulations, policies and practices are in harmony with international environmental obligations

- not to seek to gain trade or investment advantage by weakening or detracting from their environmental laws and regulations

- not to use their environment laws, regulations, policies and practices for trade protectionist purposes

- to promote public awareness of their environmental laws, regulations, policies and practices domestically, and to ensure the processes for the operation and enforcement of their environment laws are fair, equitable and transparent (New Zealand Ministry for the Environment, n.d.).

The New Zealand-China Environment Cooperation Agreement provides an additional platform for cooperation between the two countries. In the preamble, intent to strengthen cooperation on environmental matters is expressed by the Parties "DESIRING to strengthen the growing economic and political relationship between New Zealand and the People's Republic of China; SHARING a common aspiration to promote sound environmental policies and practices and a common concern and responsibilities to enhance cooperation including to improve the capacities and capabilities of both countries, including non-government sectors, to address environmental matters; and towards the promotion of sustainable development, noting it is essential for economic prosperity; ACKNOWLEDGING the regional and global nature of environmental issues and the need to find cost-effective and long-term solutions in addressing these issues through international cooperation and the importance of coordinating joint activities of the two Parties".

Article 2 provides " 1 . Taking account of their national priorities and available resources, the Parties agree to cooperate on environmental matters of mutual interest and benefit. The Parties shall jointly decide specific environment cooperative activities. 
2. Cooperative activities may be in areas including but not limited to: environmental management, environmental remediation, nature conservation, and technologies (including systems and processes) for environmental benefit. Examples could include:

(a) Management of water environment;

(b) Coastal ecological conservation and pollution control;

(c) Air pollution control and monitoring;

(d) Improvement of environmental awareness, including environmental education and public participation;

(e) Management and disposal of waste including hazardous waste;

(f) Environmental management of chemicals;

(g) Environment and trade;

(h) Biodiversity conservation; and

(i) Other areas as mutually agreed upon.

3. Cooperative activities may be implemented through a variety of means including in the following forms:

(a) exchange of relevant experiences, environmental information and documentation;

(b) exchange of visits of experts, scholars and delegations;

(c) jointly organized seminars, workshops, projects, studies and meetings attended by scientists, experts, regulators and others concerned, including in conjunction with international forums and matters; and

(d) other forms of cooperation as mutually agreed upon.

4. Each Party may, as appropriate, invite the participation of other organisations in identifying potential areas for cooperation and in undertaking cooperative activities. To implement this Agreement both Parties shall encourage environmental protection organisations, enterprises and municipalities as well as research institutions and other entities on both sides to establish and develop direct contacts with each other in the field of environmental protection and sustainable development."

Further articles relate to the implementation of the agreement including funding of cooperative activities, and monitoring and evaluation of the progress of implementation, dispute settlement, and the entry into force of the agreement. 


\section{Canada-Peru Agreement on the Environment}

The Agreement on the Environment between Canada and Peru commits both countries to pursue high levels of environmental protection and to continue to strive to develop and improve their environmental laws and policies. It commits the Parties to:

- comply with and effectively enforce their domestic environmental laws;

- not derogate from domestic environmental laws to encourage trade or investment;

- ensure that proceedings are available to sanction or remedy violations of environmental laws;

- increase public awareness of environmental laws and policies by ensuring that information regarding environmental laws and policies is available to the public;

- ensure that environmental impact assessment processes are in place;

- encourage the use of voluntary best practices of corporate social responsibility (CSR) by enterprises;

- $\quad$ strengthen the protection of biological diversity; and

- respect, preserve and maintain traditional knowledge, innovations and practices of indigenous and local communities (Foreign Affairs and International Trade Canada, n.d.).

The Agreement contains provisions related to the enforcement of environmental standards, the management of the agreement, dispute resolution, environment-related cooperation activities and information exchange, a review of the agreement and others. 


\section{REFERENCES}

Foreign Affairs and International Trade Canada (n.d.), An Agreement on the Environment between Canada and the Republic of Peru, $<$ www.international.gc.ca/trade-agreementsaccords-commerciaux/agr-acc/peru-perou/fs-environ.aspx $>$.

Loeb, H., S. Flicker and C. Han (2008), "How to Save the U.S.-Korea Free-Trade Deal", in Business Week, Insight, 27 June 2008, available at $<$ www.businessweek.com/globalbiz/content/jun2008/gb20080627_203913.htm>, accessed 5 October 2008.

New Zealand Ministry for the Environment (n.d.), International Trade and Environment, $<$ www.mfe.govt.nz/laws/trade/trade.html\#what $>$.

New Zealand Ministry of Foreign Affairs and Trade (2007), "Gulf Cooperation Council (GCC) / New Zealand Free Trade Agreement - Background Information Paper", available at $<$ www.mfat.govt.nz/downloads/trade-agreement/gcc/gcc-background-infopapermar07.pdf $>$, accessed 5 October 2007.

Office of the United States Trade Representative (2007), "Bipartisan Trade Deal”, Bipartisan Agreement on Trade Policy, May 2007, available at $<$ www.ustr.gov/assets/Document_Library/Fact_Sheets/2007/asset_upload_file127_11319.p df $>$, accessed 8 February 2009.

Office of the United States Trade Representative (2008a), "United States and Uruguay Continue to Advance Bilateral Trade Relations by Signing Two Protocols to the United States Uruguay Trade and Investment Framework Agreement”, Press Release, 2 October 2008, available at

$<$ www.ustr.gov/Document_Library/Press_Releases/2008/October/United_States_Uruguay_ Continue_to_Advance_Bilateral_Trade_Relations_by_Signing_Two_Protocols_to_the_Unit ed_States_Uruguay_T. $\bar{h}$ tml $>$, accessed $\overline{5}$ October $\overline{2} 00 \overline{8}$.

Office of the United States Trade Representative (2008b), "United States to Negotiate Participation in Trans-Pacific Strategic Economic Partnership", Fact Sheet, September 2008, available at $<$ www.ustr.gov/assets/Document_Library/Fact_Sheets/2008/asset_upload_file660_15116.p df $>$, accessed 5 October 2008. 